\title{
Soviet Dissidents and the Legacy of the 1917 Revolutions
}

\section{B. Martin}

For citation: Martin B. Soviet Dissidents and the Legacy of the 1917 Revolutions. Vestnik of Saint Petersburg University. History, 2019, vol. 64, issue 1, pp. 107-119. https://doi.org/10.21638/11701/ spbu02.2019.106

This article seeks to explain why, as the dissident movement burgeoned in the Soviet Union in the 1960s, there was almost no discussion about the October Revolution in samizdat, and it was the anti-Stalinist motif that predominated instead. It argues that at the time anti-Stalinism constituted a unifying language of activism for the "sixtiers" generation for several reasons: their communist upbringing; family ties to repressed communists; and the tacit acceptance of Khrushchev's de-Stalinization as a reformist framework for their action. As they feared Stalin's public rehabilitation, anti-Stalinism became the most pressing cause, pushing any deeper reflection on the regime's legitimacy into the background. However, by the 1970s, as a result of increased repression and the growing isolation of dissidents, the movement had split into several currents. An avowedly non-political current, the human rights movement emerged as a result of the rejection of revolutionary violence. Renouncing the prospect of regime change, it staked instead on a "legalist" strategy, which precluded any questioning of the Revolution as the foundation of the current regime. By contrast, for the more politicized Russophile current represented by Aleksandr Solzhenitsyn, and for the democratic socialist current embodied by Roy Medvedev, it became important to affirm their vision of the Revolution and its place in history in order to affirm their own political programs. While Medvedev sought to offer a demythologized account of the October Revolution to bolster its legitimacy, Solzhenitsyn denounced the February Revolution as a fateful caesura in Russian history.

Keywords: Soviet Union, dissidence, dissent, October Revolution, de-Stalinization, human rights.

Barbara Martin - PhD, Associated Researcher, the Pierre du Bois Foundation for Contemporary History, Ch. Jean-Pavillard, 22, 1009 Pully Switzerland; barbara.martin@graduateinstitute.ch, barbara. martin74@gmail.com

Барбара Мартин - $\mathrm{PhD}$, ассоциированный исследователь, Фонд современной истории Пьера Дюбуа, Швейцария, 1009, Пюли, ул. Жан-Павийар, 22; barbara.martin@graduateinstitute.ch, barbara. martin74@gmail.com

This article was written in the framework of a project funded by the Swiss National Foundation for Science. An early version of this article was presented at the conference "Trajectories of October: Origins, Reverberations and Models" in Paris (October 19-21, 2017).

Статья подготовлена в рамках проекта, финансируемого Швейцарским национальным фондом науки. Ранняя версия этой статьи была представлена на конференции «Траектории Октября: истоки, отголоски и модели» в Париже (19-21 октября 2017 г.)

(c) Санкт-Петербургский государственный университет, 2019 


\section{Советские диссиденты и наследие революций семнадцатого года}

\section{Б. Мартин}

Для цитирования: Martin B. Soviet Dissidents and the Legacy of the 1917 Revolutions // Becтник Санкт-Петербургского университета. История. 2019. Т. 64. Вып. 1. С. 107-119. https://doi. org/10.21638/11701/spbu02.2019.106

В статье рассматривается вопрос о том, почему в эпоху процветания советского диссидентского движения 1960-х годов в Самиздате не предпринималось дискуссий об Октябрьской революции, а вместо этого преобладала антисталинская тематика. На первом этапе десталинизации, начавшейся в 1956 г., приоритетным был поиск путей возвращения к «истинному ленинизму». При этом попытки нового прочтения ленинских текстов не только не давали желаемых ответов, но и были чреваты репрессиями. Приводится довод, согласно которому антисталинизм в то время являлся объединяющим языком для активистов поколения «шестидесятников» по нескольким причинам: в силу их коммунистического воспитания, семейных связей с репресированными коммунистами, а также молчаливого принятия для своей деятельности реформистских рамок хрущевской десталинизации. Перед лицом угрозы публичной реабилитации Сталина антисталинизм стал самым актуальным делом, а более глубокие вопросы о легитимности режима отошли на задний план. Однако к началу 1970-х годов вследствие усилившегося нажима со стороны властей и нарастающей изоляции диссидентов движение раскололось на несколько течений. Одно течение - правозащитное - решительно отказалось от революционного насилия и отвернулось от политики. Вместо того, чтобы бороться за смену режима, правозащитники делали ставку на стратегию «законности», тем самым исключая возможность какого-либо размышления об истории Октябрьской революции, основах советского режима. Напротив, для более политизированных участников движения, главы русофильского течения А.И.Солженицына или представителя демократического социалистического течения Р.А. Медведева, было необходимо утвердить собственные концепции революции и ее места в истории для продвижения своих собственных политических программ. В то время как Медведев стремился развеять мифы об Октябрьской революции, чтобы более прочно утвердить ее легитимность, Солженицын разоблачал Февральскую революцию как трагический разрыв в русской истории.

Ключевые слова: Советский Союз, диссидентство, инакомыслие, Октябрьская революция, десталинизация, права человека.

In his 1975 overview of historical samizdat, Western Sovietologist Robert Slusser noted that "the historical problem most passionately debated in dissident intellectual circles in the Soviet Union is the historical role of Stalin"1. This predominance comes to the fore when one considers the corpus of texts circulated underground and published in the West, from Gulag memoirs and anti-Stalinist protest letters to the most emblematic dissident histories, Aleksandr Solzhenitsyn's “GULAG Archipelago" and Roy Medvedev's "Let History Judge". This begs the question of why this theme came to overshadow what may seem at first glance to be the most pressing question for Soviet dissidents: the meaning of the October Revolution in Russian history. As dissidents challenged the authority of the Communist Party in the post-Stalin era, one could have expected them to ques-

${ }^{1}$ Slusser R.M. History and the Democratic Opposition // Dissent in the USSR: Politics, Ideology and People / ed. by R. Tökes. Baltimore, 1975. P. 334. 
tion the historical foundations of its monopoly on power, starting from the overthrow of the Provisional Government in October 1917.

Based on memoirs of Soviet dissidents and their historical writings, this article analyzes why 1937 took precedence over 1917 in samizdat and tamizdat texts of the 1960s and early 1970s, and shows in which circumstances the theme finally emerged in the late 1970s in the writings of such authors as Solzhenitsyn and Medvedev. I argue that both personal and political factors prevented the generation of the 1960s, the shestidesiatniki, from openly questioning the Revolution. Anti-Stalinism became the unifying language of activism for broad groups within the Soviet intelligentsia, who inscribed their action within the state-sanctioned framework of de-Stalinization. As repression against dissent increased, and the human rights movement coalesced around a set of principles and values, the adoption of a "legalist" strategy of action went along with a tacit acceptance of the regime's legitimacy, which precluded any questioning of its historical and ideological foundations. However, for the dissidents who did not renounce political action and espoused various ideological views, the presentation of new political programs required taking a stance on the meaning of the October Revolution and its legacy.

By presenting the dissidents' re-evaluation of the October Revolution as a slow process and emphasizing their initial closeness to official ideology, this article contributes to the re-examination of the Khrushchev and Brezhnev eras in recent historiography. While Cold-War era accounts traditionally portray Soviet dissidents as anti-Communist warriors fighting an oppressive regime, this article takes a longer view of their trajectory, emphasizing their progressive estrangement from communist ideology and their initial reluctance to question the regime's foundations for personal, political and tactical reasons.

\section{Back to Leninism: The shestidesiatniki's quest for answers}

The generation usually identified as "sixtiers" (shestidesiatniki), sometimes also called the "Thaw Generation", following Liudmila Alekseeva's famous memoirs ${ }^{2}$, has traditionally been considered the backbone of the Soviet dissident movement. But it also encompassed broader circles who "thought differently" (inakomysliashchie): reformist intellectuals who sought to change the system from within, petition signatories who would later retreat into conformism, and samizdat readers who were otherwise law-abiding citizens. Only in the late 1960s, as repression against dissent intensified, would a hard core of activists emerge, which is traditionally identified as the dissident movement. This generation was characterized by a number of common experiences, which influenced the shestidesiatniki's approach to Soviet history and their strategies of public action in the 1960s.

Born in the first two decades following the Revolution, the "sixtiers" grew up at the height of Stalin's personality cult. Some of them, like the twin brothers Roy and Zhores Medvedev, grew up in communist families, and for them devotion to their parents and to the Revolution were often tightly interwoven ${ }^{3}$. Others, like Dina Isaakovna Kaminskaia, a future lawyer of dissidents, remained oblivious to their parents' anti-Soviet views. Although her father did not accept the Bolshevik Revolution, he "consciously avoided rais-

${ }^{2}$ Alexeyeva L., Goldberg P. The Thaw Generation: Coming of Age in the Post-Stalin Era. Pittsburgh, 1993.

3 Medvedev R. A., Medvedev Zh. A. 1925-2010. Iz vospominanii. M., 2010. P. 10-11. 
ing [her] in an anti-Soviet spirit". As a result, she "grew up a thoroughly 'Soviet' child", and joined the communist youth organization like her classmates ${ }^{4}$.

Among the common formative experiences that the shestidesiatniki went through, the most traumatic event was arguably the 1937-38 Terror. For many children of the intelligentsia and of the party elite, this was associated with the loss of a parent, or the fear thereof. Some of them personally bore the brunt of the terror, experiencing arrest, or being sent away to an orphanage. Petr Iakir was just fourteen years old when his father was arrested but he was sent to a penal colony for underaged offenders; by 1944, he was old enough to earn an adult's camp term in the Gulag. Anton Antonov-Ovseenko was nineteen when he was first arrested two years after his father, and he would survive several camp terms until his release, in 1953. Nevertheless, these experiences did not necessarily breed anti-Soviet, or even anti-Stalinist sentiments. Antonov-Ovseenko recognized that it took him decades to come to the realization of Stalin's place in Soviet history ${ }^{5}$. Others, like Aleksandr Solzhenitsyn or Grigorii Pomerants, were arrested during or after the war for anti-Stalinist or anti-Soviet conversations. Their camp experience would only further open their eyes.

For sons and daughters of communists and revolutionaries, loyalty to their parents' struggle, especially when they had perished at Stalin's hands, was a potent factor of identification. Maiia Ulanovskaia, whose parents were Soviet intelligence agents arrested during the Terror, earned a camp term in 1951 for her participation in an anti-Stalinist organization. In the 1960s, she joined the dissident movement and ultimately emigrated to Israel. In her memoirs, she drew a line of continuity between the activism of successive generations of her family ${ }^{6}$. The three generations that she, her mother, and her son represented bore the same revolutionary genes: "what stepping into the revolution once [represented] for my parents, was [the basis for] my readiness to share their prisoners' fate". Therefore, her family had not experienced the "fathers and sons" dilemma".

The first stage in their evolution was the realization of the disconnect between the revolutionary ideals that they had been inculcated and the Stalin-era crimes which were soon to be publicly denounced in Nikita Khrushchev's "Secret Speech". Far from questioning the Revolution itself, the shestidesiatniki turned to Lenin's writings in search for answers to the question "what went wrong?". Under Stalin, this was a particularly dangerous path. Maiia Ulanovskaia and her student philosophical circle, which started with the reading of classical works about the Revolution before drifting towards an anti-Stalinist platform, received a 25 -year camp sentence in $1951^{8}$. As Juliane Fürst has pointed out, a high identification with the Soviet regime's norms was a common feature of Stalin-era anti-Stalinist youth groups. Moreover, the Bolsheviks' language, rooted in a history of underground revolutionary action, "lent itself to critical stances" 9 . Ironically, young activists "drew both their motivation and their language of dissent from sources which were made

${ }^{4}$ Kaminskaya D. Final Judgment. My Life as a Soviet Defence Lawyer. London, 1983. P. 18.

5 Antonov-Ovseenko A. V. Vragi naroda. M., 1996. P. 29.

6 Ulanovskaia M., Ulanovskaia N. Istoriia odnoi sem’i. New York, 1982. P. 6.

7 Ibid. P. 6.

${ }^{8}$ Ibid. P. 330. - Fortunately, they were amnestied in 1956.

${ }^{9}$ Fürst J. Prisoners of the Soviet Self? Political Youth Opposition in Late Stalinism // Europe-Asia Studies. 2002. Vol.54, no. 3. P. 362. 
available to them by the Stalinist state and which they read precisely because they took their Soviet duties seriously"10.

Khrushchev's denunciation of Stalin's crimes in the "Secret Speech" turned the tables unexpectedly and opened up for discussion a once taboo theme. However, his indictment was a partial one, which dated the beginning of Stalinism to the assassination of Sergei Kirov, in 1934, closing the debates on the early Soviet period. Nevertheless, he opened a "Pandora's box", and the shestidesiatniki were prompt to seize the opportunities offered by the new course.

The phenomenon of Marxist revisionist groups gained momentum during this period, with several famous affairs: most prominently, the arrest of the Leningrad mathematician Revol't Pimenov and his young friend Boris Vail', sentenced in 1957 to ten and six years of camp respectively ${ }^{11}$; and the condemnation of Lev Krasnopevtsev, a Moscow State University graduate student in history, for the formation of an underground group and for establishing contacts with foreigners ${ }^{12}$. As late as 1965, a group of nine activists led by Valerii Ronkin and Sergei Khakaev was arrested for editing a samizdat journal entitled "Kolokol" ("The Bell” - a title echoing the $19^{\text {th }}$ century revolutionary Aleksandr Herzen's publication in exile). These groups followed similar trajectories, moving from the reading of the Marxist classics to independent reflection on Soviet history and politics, but came to different conclusions, from radical anti-Stalinism to a critique of the Bolsheviks' action. In their theoretical work entitled "From the dictatorship of the bureaucracy to the dictatorship of the proletariat", Ronkin and Khakaev showed, for instance, "how Lenin and the [Central Committee] progressively retreated from the principles contained in [Lenin's] 'The State and the Revolution', creating a powerful bureaucratic apparatus, standing out of control, not only of the people, but even of rank-and-file party members"13. They harnessed the regime's ideological discourse to advocate a "true Leninism", which they claimed the Soviet state had betrayed. According to Robert Hornsby, the ideology of many Marxist revisionist groups was "suffused with a deep sense of egalitarianism and distaste for bureaucrats and 'fat-cat' political leaders" and closely related to communist values of social justice ${ }^{14}$. Their discourse showed the extent to which these young and educated critics of the regime had internalized the system's values and ideological language. Benjamin Tromly has described Marxist revisionism within Soviet universities as one of the responses to the challenges posed by Khrushchev's "Secret Speech". It was more common among students of philosophy or history — disciplines dominated by Marxist ideology — who often had an experience of party life, and who had come to apply methods of critical thinking learnt in university to re-interpret the regime's ideology $y^{15}$.

These Marxist revisionist groups corresponded to a first stage in the development of Soviet dissent and to a first re-examination of the history of the Revolution, but they also

10 Ibid. P. 357.

11 Hornsby R. Protest, Reform and Repression in Khrushchev's Soviet Union. Cambridge, 2013. P. 104-105; Tromly B. Intelligentsia Self-Fashioning in the Postwar Soviet Union. Revol't Pimenov's Political Struggle. 1949-57 // Kritika, 2012. Vol.13, no. 1. P. 171-173.

12 Hornsby R. Protest, Reform and Repression. P. 105-106.

13 Ronkin V.E. Na smenu dekabriam prikhodiat ianvari... Vospominaniia byvshego brigadmil'tsa i podpol'shchika, a pozzhe - politzakliuchennogo i dissidenta. M., 2003. P. 165.

14 Hornsby R. Protest, Reform and Repression. P. 102.

15 Tromly B. Making the Soviet Intelligentsia: Universities and Intellectual Life under Stalin and Khrushchev. Cambridge, 2014. P. 147-150. 
pointed to the limits of underground action. After his psychiatric hospitalization following his involvement with a "Union of True Leninists", General Petr Grigorenko thus came to the realization of the necessity to abandon the underground, where, as the title of his memoirs went, "one can only meet rats" ${ }^{16}$. Like Grigorenko, Liudmila Alekseeva was a Communist Party member who turned to Lenin's writings in search of answers. She entertained no doubts concerning the necessity of the revolution, yet she did not see Soviet society moving in the right direction. "There had to be a problem somewhere, perhaps a wrong turn. I realized that the only way to find that misstep would be to start at the source: I had to read Lenin from cover to cover"17. Yet these readings did not bring any new answers. Grigorenko found himself cherry-picking in Lenin's works the elements that fitted with his own ideas, while ignoring those which contradicted his views ${ }^{18}$. Both he and Alekseeva would eventually turn to the human rights movement, but like many other activists of their generation, they would only progressively shed their erstwhile views on Soviet history and communist ideology.

With the $22^{\text {nd }}$ Congress of the CPSU, in 1961, official de-Stalinization reached a peak. Despite his ideological zigzags, Khrushchev seemed to offer a framework of interpretation that could potentially assuage the shestidesiatnikis doubts, and his promise to "restore Leninist legality" gave grounds for hope. The publication of works on the hitherto taboo theme of the Gulag elicited tremendous enthusiasm within the liberal intelligentsia. While the Soviet leader only inconsistently implemented his own policy, it was the threat of a repealing of de-Stalinization after 1965 that first prompted protests, as the shestidesiatniki rallied around the unifying anti-Stalinist cause.

\section{Anti-Stalinism as the Common Language of Liberal Activism in the 1960s}

Khrushchev's ouster from power in October 1964 was caused by what his successors characterized as a mishandling of political affairs in a whole array of fields, from the economy and agriculture to foreign policy, and by his authoritarian political management ${ }^{19}$. De-Stalinization was probably not their primary concern, but there seems to have been a consensus within the new leadership on the necessity to end the excessive "blackening" of Soviet history and to offer a more "balanced" reappraisal of some episodes of the Stalin era: the Great Patriotic War, in particular, but also the history of collectivization and industrialization. In the second half of the 1960s, a growing number of positive references to Stalin appeared in Soviet print, especially in memoirs of World War II generals. Meanwhile, anti-Stalinist narratives were increasingly shoved under the carpet.

The fear that the Brezhnev leadership would officially rehabilitate Stalin caused the formation of a broad front of opposition within the liberal intelligentsia, united behind the common rallying call of anti-Stalinism. A somewhat heterogeneous coalition made of Old Bolsheviks, dissidents, and academicians thus came together to defend Aleksandr Nekrich, the author of a popular book about Stalin's responsibility for the early Soviet

16 Grigorenko P.V podpol'e mozhno vstretit' tol'ko krys... New York, 1981.

17 Alexeyeva L., Goldberg P. The Thaw Generation. P. 65-66.

18 Grigorenko P.V podpol'e mozhno vstretit' tol'ko krys... P. 490.

19 See: Schattenberg S. Leonid Breschnew: Staatsmann und Schauspieler im Schatten Stalins. Eine Biographie. Köln, 2017. S. 269-275. 
defeats during the war, which was banned from print in $1967^{20}$. In the following years, numerous writers and dissidents sent collective and individual letters to the Soviet leadership, asking for an end to the campaign to rehabilitate Stalin. A formal rehabilitation never took place: the Brezhnev leadership seems to have privileged a more consensual course, and renounced any decisive move, which would have alienated not only the intelligentsia, but also Western communist parties. The compromise position adopted by the leadership consisted in tacitly putting an end to de-Stalinization, without formally repealing the resolutions of past party congresses. This, in turn, gave added legitimacy to anti-Stalinist advocacy, as activists could call on the party to respect its own resolutions.

Anti-Stalinist protests, many of which were published in the West, thus constitute a significant corpus of samizdat documents of this period. Anti-Stalinism was so prominent in the late 1960s precisely because the cause appeared so urgent: a retreat from positions painstakingly gained during the Thaw appeared unacceptable, and it seemed, as Iakir and two other dissidents wrote in a 1968 open letter to the intelligentsia, that each silence was a step backwards and that "gradually, with your silent assent, a new 1937 could arise"21.

In these circumstances, any discussion on the Revolution seemed out of place, for several reasons. Firstly, because it was a factor of division within the heterogeneous anti-Stalinist coalition: among the opponents of Brezhnev's new course were individuals with a great range of interests, personal situations and degrees of ideological conformism. Even among those who went on to oppose the regime in the 1970s, no consensus on the question existed.

Secondly, anti-Stalinism was the only acceptable discourse of revisionism in the historical field at the time. Not only had the shestidesiatniki learned to speak the language of a "return to Leninism" in the wake of the $20^{\text {th }}$ Party Congress, in 1956, but even those who entertained serious doubts about Lenin's figure knew better than to express openly was quite "anti-Soviet" views. Questioning the official narrative concerning the Revolution was one of the strictest taboos of the regime. It was one thing to seek a return to the "pure" origins of Communism, and quite another - but to cast doubt on the validity of the Revolution itself was quite another. As dissidents left the underground and turned to open strategies of protest, they had to "speak the regime's language" if they wanted to be heard not only by the leadership, but also by their fellow countrymen. As Sergei Oushakine has pointed out, samizdat was then characterized by what he calls "a terrifying mimicry" of official discourse ${ }^{22}$. Dissidents, he argued, were constrained by Soviet society's existing "regime of truth": in order for their own discourse to be perceived as "truthful", they had to "mimetically replicate" the dominant ideological discourse ${ }^{23}$. However, I would argue that it was not just a constraint, but also a conscious strategy of action: staking on the party's unwillingness to contradict its own ideological course, anti-Stalinists activists deliberately resorted to a rhetoric they knew could have an impact on the leadership. Therefore, we may consider anti-Stalinism as a language used for airing grievances, which actually went beyond the mere struggle against Stalin's rehabilitation. And the debate on the Stalin ques-

20 "June 22, 1941": Soviet Historians and the German Invasion / ed by V.Petrov. Columbia (S. C.), 1968. On the "Nekrich affair", see his memoirs: Nekrich A. Forsake Fear: Memoirs of an Historian. Boston, 1991.

${ }^{21}$ Gabai I., Kim Iu., Iakir P. K deiateliam nauki, kul'tury i iskusstva // Antologiia samizdata: Nepodtsenzurnaia literatura v SSSR 1950-e - 1980-e. Ed. by V. Igrunov. M., 2005. P. 46-50.

22 Oushakine S. The Terrifying Mimicry of Samizdat // Public Culture, 2001, Vol. 13, no. 2. P. 191-214.

23 Ibid. P. 208. 
tion may to some extent be regarded as a substitute for the more subversive debate on the October Revolution and socialism as a whole.

Grigorii Pomerants thus wrote in his memoirs about his "feeling of internal freedom", as he prepared his anti-Stalinist speech "On the Moral Make-up of a Historical Figure". Read at the Institute of Philosophy of the Academy of Sciences in December 1965, it immediately became a samizdat "bestseller". "It was, to a certain degree, a game", recalled Pomerants. He tried to walk a fine line, "to give an example of oppositional speech, but without repression" 24 . In retrospect, he confessed that "the critique of Stalinism from Leninist positions is not always convincing". But at the time, he had "attempted to extract from the Marxist language everything possible for the criticism of Stalin" 25 .

The anti-Stalinist critique was not merely an "Aesopian language" based on official ideological jargon, however, but was also meaningful for many shestidesiatniki, who still shared the Soviet regime's core values and ideological references. It can be related to the strategy of "legality" elaborated by human rights activists, starting from 1965, which is examined in the following section. The language of democratization, glasnost', and the rule of law used by the human-rights movement did not seem necessarily at odds with socialism. At least until the invasion of Czechoslovakia in 1968, most liberal intellectuals considered "socialism with a human face" a reasonable option of peaceful evolution towards democracy, without abandoning the Revolution's social achievements.

\section{The Human Rights Movement's Ambiguous Stance on the Revolution}

Towards the end of the 1960s, with the increase of repression against petitioners and the loss of faith in the possibility of influencing the Soviet leadership, anti-Stalinism lost its appeal as a unifying cause. Those who persisted in their activism increasingly used the language of human rights and law to voice their grievances and ostensibly shunned politics. Behind this shift from a political to a legal reasoning was both a change of strategy of action and an "ethical revolution" leading to the rejection of the revolutionary mantra "the end justifies the means", invoked to defend the use of violence. Dissident memoirs reflect this progressive moral shift. Pomerants remembered experiencing such a turning point around 1960, when at a birthday party, his future wife Zinaida Mirkina had stood up to an inebriated Petr Iakir who called for the execution of Stalin's henchmen. She objected that their execution would only constitute a perpetuation of their evil deeds. Another time she refused a toast "to a new revolution". For Pomerants, dissidence was first and foremost "a form of overcoming of the political immorality, the attempt to create a movement standing outside politics, a purely ethical movement..."26

Beyond this instinctive rejection of violence, the question that arose for those activists who wished to change the Soviet system was that of the genealogy of their movement and its identity. Many shestidesiatniki identified with the pre-revolutionary intelligentsia, and believed, in Jay Bergman's words, "that their historical mission [was] to act just as courageously and altruistically as their forebears did a century earlier" 27 . Yet they also realized the ambi-

24 Pomerants G. Zapiski gadkogo utenka. M.; SPb., 2012. P. 309.

25 Ibid. P. 310-11.

26 Ibid. P. 287-88.

27 Bergman J. Soviet Dissidents on the Russian Intelligentsia, 1956-1985: The Search for a Usable Past // Russian Review. 1992. Vol.51, no. 1. P. 23. 
guity of the spiritual filiation that they claimed. Indeed, there was an obvious connection between the $19^{\text {th }}$ century intelligentsia, characterized by its alienation and criticism of the political order, and its later Bolshevik incarnation. Before the Revolution "raised" a whole generation of sons of workers and peasants, its vanguard had been constituted of intellectuals. For the shestidesiatniki, who had been raised in the revolutionary romantic spirit of the 1920s, the temptation was great to identify with the $19^{\text {th }}$ century revolutionaries, from the Decembrists, who had defied Nicholas I, to Aleksandr Herzen. But as time went on, the revolutionary groups turned more violent: the "People's Will" activists, had gradually shifted from a populist rhetoric to terrorism to reach their goals; and the Bolsheviks had founded in violence a repressive state, which had left unfulfilled its promises of prosperity for the masses.

The success met by Mikhail Shatrov's popular trilogy, composed of three related plays, "The Decembrists", "The People's Will" and "The Bolsheviks", shown at the "Sovremennik" Theater during the anniversary year 1967, was indicative of the great interest raised by this theme. Roy Medvedev commented on the play in his samizdat journal "Political Diary": "Through all of the shows runs the theme of the people's readiness for the revolution and socialism, and also the question of the limits, the necessity and possibility of terror in such and such conditions" ${ }^{28}$. The People's Will exercised a widespread fascination within the Soviet dissident community. Liudmila Alekseeva thus found that they were "remarkably intelligent people, and [she] could sympathize with some of their arguments" 29 . In her memoirs, she wrote of the dissidents' desire to "lay claim to the values" of the old intelligentsia, persecuted by the Tsars and destroyed by Stalin. They had made theirs the two central questions asked by their predecessors: "What is to be done?" (from Nikolai Chernyshevskii's book) and "Who is to blame?" (a novel by Herzen) ${ }^{30}$. And when seven dissidents unfolded their banners on Red Square to protest the Czechoslovak invasion, they used Herzen's slogan in support of the Poles "To your freedom and ours"

Despite her fascination with the history of the Russian revolutionary movement, Alekseeva did not fully explore this connection, which was bound to have problematic implications. As Bergman emphasized, questioning the Russian intelligentsia's responsibility for the October Revolution raised the issue of a betrayal of its original values and ideals, and the equally problematic question of what had gone wrong, and when? The dissidents who raised the issue did so with regret and "with a certain bewilderment that a group of persons so seemingly similar to themselves should have helped to precipitate a revolutionary cataclysm so catastrophic in its historical consequences"32.

An answer to this agonizing conundrum was the rejection both of violence and of conspiratorial methods of action, which had been used by previous generations of revolutionaries. By then, new forms of activism were making headway among democratic activists, emphasizing the notion of glasnost' (transparency) and legalism. The first stone was laid by the "Glasnost' demonstration" organized by Aleksandr Esenin-Vol'pin on December 5, 1965 - Soviet Constitution Day - and attended by over a hundred people. Esenin-Vol'pin's call for the respect of transparency in the forthcoming trial of the writers

${ }^{28}$ Medvedev R.A. Trilogiia o revoliutsionnerakh v teatre "Sovremennik". Politicheskii Dnevnik, December 1967 // Arkhiv istorii inakomyslii v SSSR (1953-1987). Mezhdunarodnyi memorial. F. 128. Box 1.

${ }^{29}$ Alexeyeva L., Goldberg P. The Thaw Generation. P. 80.

30 Ibid. P. 97.

31 Ibid. P. 219.

32 Bergman J. Soviet Dissidents on the Russian Intelligentsia. P. 25-26. 
Andrei Siniavskii and Iulii Daniel' and for observance of the constitution was fundamentally new. Breaking as it did with previous revolutionary traditions, this rhetoric of "civil obedience", as Benjamin Nathans has characterized it, would lay the ground for a new approach to activism ${ }^{33}$. Behind it lay a simple idea: Soviet laws were formally good, but many of them only existed on paper. Calling for the constitution to be respected could not be deemed anti-Soviet, it was a deliberately non-subversive and unpolitical demand. Adopting this strategy, however, meant tacitly accepting the rules of the game: to avoid giving the authorities any ground for repression, dissidents would not question the regime's ideological foundations. This meant forsaking any reflection on the Revolution.

However, political forms of dissent had not disappeared, and for both sides of the political spectrum, from the Russophiles to the reformist socialists, the Revolution constituted an important fault line, which deserved to be re-examined.

\section{Aleksandr Solzhenitsyn's and Roy Medvedev's Antagonistic Views on the Revolution}

Although Solzhenitsyn and Medvedev are more well-known for their writings on political repression and Stalinism, they eventually turned to the history of the Revolution for the same reasons that had prompted them to write about the Stalin era. Medvedev developed in his writings a political program of democratization of the Soviet system, which he most prominently laid out in his essay "On Socialist Democracy" (1972). His enquiry into the causes and consequences of Stalinism had been motivated by his wish to purge the Soviet system from the remnants of the Stalin era. Re-examining the history of the Revolution and purging it from the myth-making of official historiography was therefore in line with his approach aimed at strengthening the regime's legitimacy and purging Soviet history from the "distortions" of the Stalin era.

Solzhenitsyn, on the other hand, regarded Soviet political repression as the product of the communist regime, independently of the rulers in power. The question of the Revolution as a crucial rupture in Russian history was therefore fundamental in the writer's political and historical conception.

Medvedev was the first dissident author to show consistent interest in the history of the Revolution in the 1960s. He first tackled the theme in his samizdat journal "Political Diary", which he edited between 1964 and 1970 and partly published in the West in 1972-1975"34. Starting out with an attempt to restore the "true" history of the Revolution, obscured by decades of Stalin-era falsifications, he then began to tackle moral issues, such as the question of the end and the means. It was only in the mid-1970s, however, that he would lay out his historical conception of the Revolution in print. In an essay published in three successively enlarged versions between 1975 and $1979^{35}$, he concluded that the October Revolution, like any historical event, could not be considered "inevitable" or "predictable", due to the histori-

${ }^{33}$ Nathans B. The Dictatorship of Reason: Aleksandr Vol'pin and the Idea of Rights under "Developed Socialism" // Slavic Review. 2007. Vol.66, no. 4. P. 630.

${ }_{34}$ [Medvedev R. A.] Politicheskii Dnevnik. 1964-1970. Amsterdam, 1972; Medvedev R. A. Politicheskii Dnevnik II. 1965-1970. Amsterdam, 1975.

${ }_{35}$ Medvedev R. A.: 1) The October Revolution and the Problem of History as a Law-Governed Process // The Samizdat Register / ed. by R. A. Medvedev. Vol. 1. London, 1977. P. 1-72; 2) La Révolution d'Octobre était-elle inéluctable? Paris, 1976; 3) The October Revolution. New York, 1979. 
cal circumstances, but instead resulted from a whole series of contingencies. Without Lenin, who had played a central role in the takeover, the Revolution might not have taken place. He criticized the Bolsheviks for taking radical action prematurely and trying "to solve tasks for which neither the objective nor the subjective conditions existed" ${ }^{36}$. They also bore a historical responsibility for failing to avert a bloody civil war: the horrors of the "Red Terror", in particular, directly derived from their uncompromising policies. A testimony to the abuses that had taken place was the fate of the Cossack commander Mironov, who had sided with the Bolsheviks, but was arrested and killed in a Bolshevik prison in 1921. Medvedev published Mironov's "last letter" to Lenin in two editions of his essay. Still, the historian concluded that the Revolution was "a journey into the unknown" and that mistakes were inevitable; the question was whether one was prepared to learn from them ${ }^{37}$. Medvedev's mild critique of the Revolution thus aimed at offering a demythologized account of this foundational moment and drawing a line between the "mistakes" of the Lenin era and Stalin's "crimes". Ultimately, his objective was to reinforce the political legitimacy of the Revolution, undermined by the totalitarian drift of the Soviet regime in later years.

At the other end of the political spectrum, Solzhenitsyn's writings offered a Russophile narrative about the Revolution. In his writings, the Nobel laureate had consistently contested the term of "Stalinism", placing instead the emphasis on communist ideology as the source of corruption and evil. The need to explain the catastrophe that had befallen his fatherland in 1917 led him to write his monumental epic saga "The Red Wheel", which he had been planning since his youth. Initially conceived to encompass around twenty "knots", stretching from 1914 to the Civil War, this titanic project would never come to completion. Only the first knot, "August 1914", came out before Solzhenitsyn's expulsion from the USSR, in 1971, and three more "knots" after 1985.

In "Avgust chetyrnadtsatogo", the discussion on the Revolution followed the lines of the "fathers and sons" dilemma. In one scene, an engineer responded to his daughter's claim that "the whole intelligentsia is for the revolution" with the pessimistic judgment that "a reasonable person cannot be for the revolution, because the revolution is a long and foolish destruction"38.

In 1975, Solzhenitsyn published "Lenin in Zurich", a compilation of the chapters of "The Red Wheel" featuring Lenin, tracing back his trajectory from 1914 to the Revolution. As he was writing it, Solzhenitsyn himself was living in exile in Zurich and treading his hero's path. But his depiction of the Bolshevik leader was highly negative. According to Edward Ericson and Alexis Klimoff, Solzhenitsyn's early publication of these chapters was a way to "press his case against the many historians who respected Lenin's historical contribution and blamed Stalin for corrupting Lenin's allegedly pure revolutionary ideals". Solzhenitsyn's Lenin was "consumed by ideology, he despised Russia $<\ldots$. . He was arrogant, obsessive, cold, alienated - and successful" 39 .

But it was in a text entitled "Reflections on the February Revolution" 40 , written in 1980-1983, that Solzhenitsyn exposed his views most thoroughly. On the one hand, he

${ }^{36}$ Medvedev R. A. The October Revolution. P. 177.

37 Ibid. P. 185.

38 Solzhenitsyn A. I. Avgust chetyrnadtsatogo. Paris, 1971. P. 536.

39 Ericson E. E., Klimoff A. The Soul and Barbed Wire: An Introduction to Solzhenitsyn. Wilmington, 2008. P. 118-119.

40 Solzhenitsyn A.I.Razmyshleniia o fevral'skoi revoliutsii. URL: http://polit.ru/article/2007/03/05/ fevral/ (accessed 08.06.2018). 
ascribed an important role to ideologies. It was the success of liberal and socialist ideas within the Russian elite that had caused the fall of the monarchy. And the Orthodox Church, which should have acted as the natural counterweight to these ideas, did not live up to its mission of protection of the Tsar. Progressive ideas had even reached into the peasantry, following the agrarian reforms of $1861^{41}$. On the other hand, individual will, or the lack thereof, could precipitate the downfall of a regime. Only the Tsar himself could have protected his throne, but instead, he and his suite had surrendered without a fight. Solzhenitsyn did not spare his words of contempt for the "weak tsar" who "betrayed us". The monarch had had the courage neither to reform the country, nor to crush the opposition. It was precisely the February Revolution that had been the turning point of Russian history: it was the end of the monarchy, and not the establishment of Bolshevik power, that constituted the real caesura for the writer. In this, his views radically differed from the liberals' positive perspective on the February Revolution, who considered that it could have led to the establishment of liberal "bourgeois" democracy.

\section{Conclusion}

This article began with the paradox of the near-absence of historical explorations of the Revolution in samizdat in the 1960s and inquired into the reasons of this silence by examining the personal and political trajectories of democratic activists from the "generation of the 1960s" (shestidesiatniki). As I demonstrated, this generation, born and raised in the Soviet Union, only progressively re-examined its communist views. The first stage of questioning, in line with the official policy of de-Stalinization launched in 1956, was a rejection of Stalinism and a search for the reasons of the Soviet regime's departure from an allegedly "pure" Leninism. But solitary readings of Lenin's works usually raised more questions than they brought answers, and those who joined underground Marxist revisionist groups generally faced repression.

By the 1960s, the broadening of official de-Stalinization inspired renewed hope for a democratization of the Soviet system, and anti-Stalinism became a federating cause for many shestidesiatniki. It was therefore behind the rallying call of anti-Stalinism that democratic activists naturally united in the late 1960s, although their protests were less an organized movement with a positive program of action than an ad-hoc response to a perceived threat of rehabilitation of Stalin. The need to federate a broad and heterogenous front of intellectuals and party members and to make themselves heard from the authorities dictated the adoption of a communist rhetoric. The large corpus of samizdat texts produced in the 1960s therefore reflected this intermediary stage of reflection on the past, still characterized by some degree of self-censorship, but also by a genuine adherence to communist ideals on the part of many democratic activists. At this stage, questioning the Revolution seemed both irrelevant and excessively subversive. The 1960s, however, were also marked by a moral evolution and a rejection of revolutionary violence, which led to a progressive shift from a political to a legal rhetoric. In the 1970s, human rights activists repeatedly affirmed the moral and unpolitical nature of their struggle, based on legality. While they had come to reject revolutionary methods of action and had thus broken with

${ }^{41}$ Lavrov V. Fevral'skaia Revoliutsiia kak natsional'no-dukhovnaia katastrofa (A. I. Solzhenitsyn o suti togo, chto privelo k Oktiabriu i GULAGu) // Put' Solzhenitsyna v kontekste Bol'shogo Vremeni. 1918-2008. M., 2009. P. 208-214. 
the heritage of 1917, they renounced any questioning of the regime's legitimacy, which precluded any examination of the history of the Revolution.

Only in the second half of the 1970s, with the emergence of various political currents within the dissident movement, and the assertion of positive programs, would the history of the Revolution become relevant again. While the reformist socialist Roy Medvedev critically examined Lenin's action in order to reaffirm the legitimacy of the October Revolution, the Russophile Aleksandr Solzhenitsyn defined both the February and October revolutions as a tragic caesura in Russian history, leading to the triumph of a destructive ideology.

\section{References}

Alexeyeva L., Goldberg P. The Thaw Generation: Coming of Age in the Post-Stalin Era. Pittsburgh, University of Pittsburgh Press, 1993, 339 p.

Antonov-Ovseenko A. V. Vragi Naroda. Moscow, Intellekt, 1996, 366 p. (In Russian)

Bergman J. Soviet Dissidents on the Russian Intelligentsia, 1956-1985: The Search for a Usable Past. Russian Review, 1992, vol. 51, no. 1, pp. 16-35.

Ericson E. E., Klimoff A. The Soul and Barbed Wire: An Introduction to Solzhenitsyn. Wilmington, Intercollegiate Studies Institute, 2008, 289 p.

Hornsby R. Protest, Reform and Repression in Khrushchev's Soviet Union. Cambridge, Cambridge University Press, 2013, $313 \mathrm{p}$.

Fürst J. Prisoners of the Soviet Self: Political Youth Opposition in Late Stalinism. Europe-Asia Studies, 2002, vol. 54, no. 3, pp. 353-375.

Kaminskaya D. Final Judgment. My Life as a Soviet Defence Lawyer. London, Harvill, 1983, 634 p.

Lavrov V. Fevral'skaia Revoliutsiia kak natsional'no-dukhovnaia katastrofa (A. I. Solzhenitsyn o suti togo, chto privelo k Oktiabriu i GULAGu). Put'Solzhenitsyna v kontekste Bol'shogo Vremeni. Sbornik pamiati 1918-2008. Moscow, Russkii put', 2009, pp. 208-214. (In Russian)

Medvedev R. A. La Révolution d'Octobre était-elle inéluctable? Paris, Albin Michel, 1976, 187 p.

Medvedev R. A. The October Revolution. New York, Columbia University Press, 1979, 240 p.

Medvedev R. A. The October Revolution and the Problem of History as a Law-Governed Process. The Samizdat Register / ed. by Medvedev R. A. Vol. 1. London, Merlin Press, 1977, pp. 1-72.

Medvedev R. A., Medvedev Zh.A. 1925-2010. Iz vospominanii. Moscow, Izd. Prava cheloveka, 2010, 638 p. (In Russian)

Oushakine S. The Terrifying Mimicry of Samizdat. Public Culture, 2001, vol. 13, no. 2, pp. 191-214.

Nathans B. The Dictatorship of Reason: Aleksandr Vol'pin and the Idea of Rights under "Developed Socialism". Slavic Review, 2007, vol. 66, no. 4, pp. 630-663.

Pomerants G. Zapiski gadkogo utenka. Moscow; St. Petersburg, Tsentr gumanitarnykh initsiativ, 2012, 463 p. (In Russian)

Ronkin V.E. Na smenu dekabriam prikhodiat ianvari... Vospominaniia byvshego brigadmil'tsa i podpol'shchi$k a$, a pozzhe - politzakliuchennogo i dissidenta. Moscow, Zven'ia, 2003, 478 p. (In Russian)

Schattenberg S. Leonid Breschnew: Staatsmann und Schauspieler im Schatten Stalins. Eine Biographie. Köln, Böhlau Verlag, 2017, $661 \mathrm{p}$.

Slusser R. M. History and the Democratic Opposition. Dissent in the USSR: Politics, Ideology and People. Ed. by R. Tökes. Baltimore, John Hopkins University Press, 1975, pp. 329-353.

Solzhenitsyn A. I. Avgust chetyrnadtsatogo. Paris, YMCA-Press, 1971, 573 p. (In Russian)

Tromly B. Intelligentsia Self-Fashioning in the Postwar Soviet Union. Revol't Pimenov's Political Struggle. 1949-57. Kritika, 2012, vol. 13, no. 1, pp. 151-176.

Tromly B. Making the Soviet Intelligentsia: Universities and Intellectual Life under Stalin and Khrushchev. Cambridge, Cambridge University Press, 2014, 295 p.

Ulanovskaia M., Ulanovskaia N. Istoriia odnoi sem’i. New York, Chalidze Publications, 1982, 463 p. (In Russian)

Received: June 19, 2018

Accepted: November 30, 2018

Статья поступила в редакцию 19 июня 2018 г.

Рекомендована в печать 30 ноября 2018 г. 